\title{
Pengaturan Indonesianisasi Saham Melalui Divestasi Sebagai Refleksi Sumber Daya Alam Mineral dan Batubara "Dikuasai Oleh Negara"
}

\author{
Hagrina Azkia Tamam \\ Magister Ilmu Hukum Fakultas Hukum Universitas Islam Indonesia \\ Jln. Cik Di Tiro No. 1, Yogyakarta, 55223 \\ hagrinazkia@gmail.com
}

\begin{abstract}
This study discusses first, amendments in the regulation of Indonesianization of Shares in Law Number 4 of 2009 and their impact on the country and the foreign investment. Second, whether the Indonesianization of shares through investment in Indonesian shares reflect the notion of "controlled by the state" is in accordance to what has been mandated in Article 33 point (3) of the Constitution of 1945. The research method used in this study is normative-juridical. The results of the study conclude that, first, amendments in the regulation on divestment of shares cause the lack of legal certainty for the State, the foreign investors, and the prospective foreign investors in the mining sector. Second, the divestment regulation of shares does reflect the notion of "controlled by the state" as mandated in Article 33 paragraph (3) of the Constitution of 1945.
\end{abstract}

Keywords: Indonesianization; divestmentmining; controlled by state

\begin{abstract}
Abstrak
Penelitian ini membahas mengenai pertama, perubahan pengaturan Indonesianisasi Saham dalam Undang-Undang Nomor 4 Tahun 2009 serta dampaknya bagi negara dan penanaman modal asing. Kedua, apakah Indonesianisasi saham melalui divestasi saham di Indonesia telah merefleksikan makna "dikuasai negara" sebagaimana diamanatkan dalam Pasal 33 ayat (3) Undang-Undang Dasar 1945. Metode penelitian yang digunakan adalah yuridis normatif. Hasil penelitian menyimpulkan, pertama, perubahan mengenai ketentuan divestasi saham mengakibatkan ketidak pastian hukum bagi negara, penanam modal asing, dan calon penanam modal asing di bidang pertambangan. Kedua, pengaturan divestasi saham memang sejatinya telah merefleksikan nosi "Dikuasai Oleh Negara" sebagaimana yang telah diamanatkan dalam Pasal 33 ayat (3) Undang-Undang Dasar 1945.
\end{abstract}

Kata-kata Kunci: Indonesianisasi saham; divestment; pertambangan; dikuasai oleh negara 


\section{Pendahuluan}

Penanaman modal atau Investasi merupakan hal yang penting bagi pembangunan ekonomi suatu negara, khususnya investasi modal langsung (direct investment). Hingga saat ini investasi diyakini memiliki kontribusi yang besar dalam menopang pembangunan ekonomi suatu bangsa. Menurut Eddy Cahyono, investasi memiliki peran sebagai salah satu komponen penting dalam mendongkrak pendapatan nasional,1 terutama dalam hal menunjang, mempercepat pembangunan dan pertumbuhan ekonomi.

Kebutuhan modal idealnya dapat disediakan oleh kemampuan modal dalam negeri, baik melalui pemerintah maupun dengan bantuan swasta dalam negeri. ${ }^{2}$ Akan tetapi, kenyataan yang terjadi tidaklah demikian. Negara-negara terutama negara berkembang mengalami berbagai kendala dalam hal ketersediaan modal yang cukup untuk dapat melaksanakan pembangunan secara menyeluruh. Beberapa kendala tersebut antara lain; 1. Tingkat tabungan (saving) masyarakat masih rendah, akumulasi modal yang belum efektif dan efisien; 2 . Sumber daya manusia, keterampilan (skill) yang belum memadai, dan 3 . Teknologi, belum tersedianya teknologi maupun teknologi modern. ${ }^{3}$

Kendala-kendala tersebut pada umumnya dapat diatasi melalui bantuan kerjasama dengan luar negeri atau asing, dengan mengunakan mekanisme penanaman modal.

Pada awal era kemerdekaan pemerintah Indonesia pernah mengalami kesulitan dalam melaksanakan pembangunan akibat keterbatasan dana, ${ }^{4}$ yang menyebabkan Indonesia tertinggal dibandingkan negara-negara ASEAN lainnya. Ketertinggalan tersebut terjadi akibat kebijakan pada era Soekarno yang membatasi penerimaan modal asing, terutama pada bidang pertambangan.

\footnotetext{
1 Eddy Cahyono, Investasi dan Pembangunan Ekonomi, lihat https://setkab.go.id/investasi-danpembangunan-ekonomi/ diakses pada 7 April 2019.

2 Aminuddin Ilmar, Hukum Penanaman modal Indonesia, Kencana, Jakarta, 2004, hlm. 2-4.

${ }^{3}$ Ibid.

4 Amin Bendar, Hukum Penanaman Modal Asing Implementasi Pertambangan di Indonesia, FH UII Press, Yogyakarta, 2018, hlm. 4
} 
Dibukanya investasi langsung pada 1967 melalui Undang-Undang Nomor 1 Tahun 1967 tentang Penanaman Modal Asing menjadi angin segar bagi penanam modal asing, terutama bagi penanam modal yang tertarik pada sektor pertambangan di Indonesia. Pembukaan arus investasi asing melalui UndangUndang Nomor 1 Tahun 1967 juga dibarengi dibarengi dengan diberlakukannya pengaturan mengenai pertambangan dalam Undang-Undang Nomor 11 Tahun 1967 tentang Ketentuan-Ketentuan Pokok-Pokok Pertambangan yang selanjutnya menjadi dasar masuknya penanaman modal di bidang pertambangan di Indonesia.

Adanya tarik ulur kepentingan antara investor dan host country tak jarang menyebabkan kebijakan hukum investasi yang telah ditetapkan terasa mandul, karena dianggap "setengah hati" dan dirasakan menimbulkan hambatan bagi para calon investor ataupun para investor. ${ }^{5}$ Tak jarang adanya perbedaan kepentingan menyebabkan salah satu pihak terutama investor tidak menjalankan kebijakan yang telah dibuat oleh host country.

Ketidaktaatan investor dalam melaksanakan kebijakan yang dibuat oleh host country juga dirasakan Indonesia. Dimana mulai 1974 Indonesia menerapkan kebijakan mengenai "Indonesianisai". Kebijakan ini didasarkan hasil Sidang Dewan Stabilisasi Ekonomi Nasional pada 22 Januari 1974 yang mewajibkan penyertaan nasional baik investasi lama maupun yang baru harus menjadi 51\% dalam jangka waktu 10 tahun. $^{6}$ Dalam perkembangannya kebijakan Indonesianisasi tersebut kemudian dikukuhkan dalam Keputusan Ketua BKPM No. 12/SK/1986 tentang Persyaratan Pemilikan Saham Nasional dalam Perusahaan Penanaman Modal Asing. ${ }^{7}$

Indonesianisasi sendiri merupakan upaya pemerintah untuk mengurangi presentase kepemilikan saham dalam investasi asing dengan cara mengalihkan

\footnotetext{
${ }^{5}$ Muchammad Zaidun, Parad..., Ibid.

${ }^{6}$ Erman Rajaguguk, Indonesianisasi Saham, Bina Aksara, Jakarta 1986, hlm. 72.

${ }^{7}$ Siti Anisah dan Lucky Suryo Wicaksono, Hukum Investasi, FH UII Press, Yogyakarta, 2014, hlm. 256.
} 
saham ke pihak lain atau Divestasi. ${ }^{8}$ Jadi, Divestasi merupakan bentuk dari pelaksanaan Indonesianisasi.

Indonesianisasi tidak saja hanya berarti pengalihan keuntungan, tetapi lebih penting lagi adalah pengalihan kontrol terhadap jalannya perusahaan. Apabila, dikaji definisi ini, ada dua hal yang dihajatkan dari konsep Indonesianisasi, yaitu; ${ }^{9}$ 1. Mendapatkan keuntungan; dan 2. Pengalihan kontrol terhadap jalannya perusahaan.

Keuntungan yang diperoleh dari Indonesianisasi adalah adanya pemasukan dan/atau keuntungan yang diperoleh dari dividen perusahaan asing. Sementara itu, apabila saham yang dimiliki mitra lokal merupakan saham mayoritas, maka mitra lokal dapat mengendalikan jalannya perusahaan tersebut. Sehingga jajaran direksi dapat ditempatkan oleh orang-orang lokal.10

Pasca pemberlakuan Undang-Undang Nomor 4 Tahun 2009 tentang Pertambangan Mineral dan Batubara, Pemerintah kembali mengatur mengenai Indonesianisasi saham melalui divestasi sebagaimana yang diatur dalam Pasal 112. Divestasi saham pada sektor pertambangan dainggap sebagai pelaksanaan dari Pasal 33 ayat (3) Undang-Undang Dasar Republik Indonesia Tahun 1945, yang menyatakan bahwa;11 "Bumi, air, dan kekayaan yang terkandung didalamnya dikuasai oleh negara dan dipergunakan untuk sebesar-besarnya kemakmuran rakyat".

\section{Rumusan Masalah}

Berdasarkan uraian di atas maka, penulis ingin menganalisis mengenai pertama, apakah perubahan pengaturan Indonesianisasi Saham dalam UndangUndang Nomor 4 Tahun 2009 tentang Pertambangan Mineral dan Batubara memberikan kepastian hukum bagi negara dan penanam modal asing? Kedua, apakah pelaksanaan Indonesianisasi saham melalui divestasi saham telah

\footnotetext{
${ }^{8}$ Divestasi diartikan sebagai pengalihan aset atau saham yang dimiliki oleh investor asing kepada pihak lainnya demi memenuhi kewajiban kontraktuan dan/atau peraturan perundang-undangan yang berlaku Siti Anisah dan Lucky Suryo Wicaksono, Hukum Inv.., hlm. 252-253

${ }_{9}$ Salim HS dan Erlies Septiana Nurbani, Hukum Divestasi di Indonesia (Pasca Putusan Mabkamah Konstitusi RI Nomor 2/SKLN-X/2010), RajaGrafindo Persada, Jakarta, 2013, hlm. 116.

${ }_{10}$ Ibid.

11 Undang-Undang Dasar Republik Indonesia Tahun 1945, Pasal 33 ayat (2).
} 
merefleksikan makna "dikuasai oleh negara" sebagaimana yang diatur dalam Pasal 33 Undang-Undang Dasar 1945?

\section{Tujuan Penelitian}

Penelitian ini bertujuan untuk mengetahui sekaligus memahami dinamika perubahan pengaturan Indonesianisasi Saham dalam Undang-Undang Nomor 4 Tahun 2009 tentang Pertambangan Mineral dan Batubara serta dampaknya bagi negara dan penanaman modal asing. Selain itu, penelitian ini untuk menganalisis pengaturan Indonesianisasi saham melalui divestasi saham di Indonesia apakah merefleksikan makna "dikuasai negara" sebagaimana diamanatkan dalam Pasal 33 Undang-Undang Dasar 1945.

\section{Metode Penelitian}

Jenis penelitian ini adalah yuridis normatif yaitu penelitian yang dilakukan terhadap norma hukum tertulis seperti peraturan perundang-undangan, yurisprudensi, traktat, kebiasaan dan lain-lain. Metode penelitian yang digunakan dalam penelitian ini, yaitu penelitian eksplanatoris. Penelitian eksplanatoris adalah penelitian yang dilakukan berdasarkan data-data yang telah ada untuk menganalisa dan menjelaskan kembali suatu permasalahan secara lebih mendalam. ${ }^{12}$

Objek penelitian yang dipakai dalam penelitian ini lebih difokuskan pada produk-produk hukum dimulai dari Peraturan perundang-undangan dan yurisprudensi yang berkaitan dengan Indonesianisasi saham. Sedangkan bahan hukum yang digunakan ialah; bahan hukum primer yaitu bahan hukum yang diperoleh dari peraturan perundang-undangan dan yurisprudensi yang berlaku dan berkaitan dengan Indonesianisasi saham. Bahan hukum sekunder yaitu bahan hukum yang diperoleh secara tidak langsung melalui buku-buku, jurnal, majalah, koran, yang berkaitan dengan permasalahan yang peneliti teliti.

${ }^{12}$ Soerjono Soekanto, Pengantar Penelitian Hukum, cet.ketiga, Universitas Indonesia, Jakarta, 1986, hlm. 10. 


\section{Hasil Penelitian dan Pembahasan}

\section{Pengaturan Indonesianisasi Saham dalam Undang-Undang Nomor 4 Tahun 2009 tentang Pertambangan Mineral dan Batubara}

Indonesianisasi saham merupakan upaya pemerintah untuk mengurangi presentase kepemilikan saham dalam investasi asing dengan cara mengalihkan saham ke pihak lain dalam negeri atau yang saat ini lebih dikenal dengan divestasi. $^{13}$ Indonesianisasi saham merupakan salah satu fokus baru dalam kebijakan ekonomi-politik pemerintahan Seoharto pada masa Orde Baru, kebijakan ini lahir setelah terjadinya peristiwa 15 Januari 1974 (Malari) yang merupakan penanda perubahan signifikan dalam kebijakan penanaman modal asing (PMA) dan Kredit di Indonesia. ${ }^{14}$

Melalui Keputusan Dewan Stabilisasi Ekonomi Nasional pada 22 Januari 1974, berupa kebijakan baru Pemerintah dalam penanaman modal asing yaitu; ${ }^{15} 1$. Penanaman modal asing di Indonesia harus berbentuk joint venture dengan modal nasional; 2. Penyertaan nasional baik dalam investasi yang lama maupun yang baru harus menjadi 51\% dalam jangka waktu 10 tahun; 3. Partner asing harus memenuhi ketentuan pengalihan tenaga kerja pada karyawan-karyawan Indonesia; 4. Partisipasi pengusaha pribumu Indonesia baik dalam penanaman modal asing maupun modal dalam negeri harus bertambah besar.

Setelah dikeluarkannya Keputusan Dewan Stabilisasi Ekonomi nasional tersebut pada pada oktober 1974 Badan Koordinasi Penanaman Modal (BKPM) mengeluarkan Surat Edaran BKPM No. B-1195/A/BKPM/X/1974 tertanggal 11 Oktober 1974.16 Isi dari Surat Edaran Tersebut pada intinya mewajibkan penanam modal yang melakukan kegiatan usaha di Indonesia untuk meningkatkan saham nasional minimum 51\% dengan jangka waktu tertentu sesuai dengan proyekproyek yang dikerjakan.

${ }^{13}$ Divestasi diartikan sebagai pengalihan aset atau saham yang dimiliki oleh investor asing kepada pihak lainnya demi memenuhi kewajiban kontraktuan dan/atau peraturan perundang-undangan yang berlaku Siti Anisah dan Lucky Suryo Wicaksono, Hukum Inv.., hlm. 252-253.

${ }^{14}$ Erman Rajaguguk, Indonesianisasi Saham, PT Bina Aksara, Jakarta, 1985, hlm. 11.

${ }^{15}$ Erman Rajagukguk, Indonesianisasi.., Ibid., hlm. 72.

${ }^{16}$ Ibid. 
Kemudian pada 1992, pemerintah akhirnya mengukuhkan kewajiban penyertaan nasional pada peraturan perundang-undangan yang lebih tinggi, yakni melalui PP Nomor 17 Tahun 1992 tentang Persyaratan Pemilikan Saham Dalam Penanaman Modal Asing. ${ }^{17}$

PP Nomor 17 Tahun 1992 secara umum mulai memberikan batas minimal persetujuan penanaman modal asing yang akan melakukan kegiatan usaha di Indonesia, dimana Perusahaan yang didirikan dalam rangka penanaman modal asing, selanjutnya disebut Perusahaan PMA, pada dasarnya berbentuk usaha patungan dengan persyaratan bahwa pemilikan modal saham peserta Indonesia dalam perusahaan patungan tersebut sekurang-kurangnya 20\% dari seluruh nilai modal saham perusahaan pada waktu pendirian perusahaan patungan, dan ditingkatkan menjadi sekurang-kurangnya 51\% dalam waktu 20 tahun terhitung sejak perusahaan berproduksi secara komersial sebagaimana tercantum dalam izin usahanya. ${ }^{18}$

Peraturan Pemerintah yang mengatur mengenai persyaratan pemilikan saham dalam penanaman modal asing sendiri tercatat telah mengalami 2 kali perubahan. ${ }^{19}$ Dalam PP Nomor 20 Tahun 1994, pengaturan mengenai kewajiban partisipasi peserta Indonesia bagi PMA dirubah dengan ketentuan bahwa; penanaman modal asing yang akan melaksanakan kegiatan usaha di Indonesia wajib berbentuk badan usaha patungan antara modal asing dengan modal yang dimiliki warga negara Indonesia dan atau badan hukum Indonesia; atau langsung, dalam arti seluruh modalnya dimiliki oleh warga negara dan/atau badan hukum asing.

Peraturan ini mengubah kewajiban partisipasi nasional yang sebelumnya $51 \%$ menjadi sekurang-kurangnya 5\% dari seluruh modal disetor perusahaan pada waktu pendirian. ${ }^{20}$ Peraturan Pemerintah ini kemudian yang menjadi acuan

\footnotetext{
${ }^{17}$ Maulana Hasanudin, Perusahaan Joint Venture, Tesis, Pascsarjana FH UI, Jakarta, 2010, hlm. 32.

18 Peraturan Pemerintah Nomor 17 Tahun 1992 tentang Persyaratan Pemilikan Saham dalam Penanaman Modal Asing, Pasal 2.

19 Perubahan pertama terjadi pada 1993 melalui Peraturan Pemerintah Nomor 50 Tahun 1993 tentang Persyaratan Pemilikan Saham dalam Perusahaan Penanaman Modal asing, dan perubahan kedua pada 1994 melalui Peraturan Pemerintah Nomor 20 Tahun 1994 tentang Persyaratan Pemilikan Saham dalam Perusahaan Penanaman Modal Asing.

20 Peraturan Pemerintah Nomor 20 Tahun 1994 tentang Persyaratan Pemilikan Saham dalam Perusahaan Penanaman Modal Asing, Pasal 6 ayat (1).
} 
bagi penanaman modal asing di Indonesia hingga diberlakukannya UndangUndang Nomor 4 Tahun 2009 tentang Pertambangan Mineral dan Batubara. ${ }^{21}$

Diberlakukannya Undang-Undang Nomor 4 Tahun 2009 tentang Pertambangan Mineral dan Batubara di Indonesia berimplikasi pada tidak lagi berlaku peraturan yang sebelumnya mengatur mengenai penyertaan modal dalam negeri atau keterlibatan peserta nasional yang diatur dalam UndangUndang Nomor 1 Tahun 1967 tentang Penanaman Modal Asing melalui peraturan pelaksana yakni PP Nomor 20 Tahun 1994.22

Indonesianisasi saham dalam Undang-Undang Nomor 4 Tahun 2009 tentang Pertambangan Mineral dan Batubara lebih dikenal dengan sebutan divestasi saham. Ketentuan mengenai divestasi saham diatur dalam Pasal 112 ayat (1) yang menyatakan bahwa; 23

"Setelah 5 (lima) tahun berproduksi, badan usaha pemegang IUP dan IUPK yang sahamnya dirniliki oleh asing wajib melakukan divestasi saham pada Pemerintah, pemerintah daerah, badan usaha milik negara, badan usaha milik daerah, atau badan usaha swasta nasional."

Sedangkan tata laksana mengenai divestasi saham secara lebih lanjut diatur dalam Peraturan Pemerintah (PP), ${ }^{24}$ yakni PP Nomor 23 Tahun 2010 tentang Pelaksanaan Kegiatan Usaha Pertambangan Mineral dan Batubara.

Divestasi saham dalam ketentuan PP Nomor 23 Tahun 2010 tertuang dalam Pasal 97 hinga Pasal 99 dimana pasal-pasal tersebut menjelaskan mengenai kewajiban pelaksanaan divestasi saham bagi modal asing pemegang IUP dan

\footnotetext{
${ }^{21}$ Salah satu penanam modal asing dibidang pertambangan yang menyatakan diri tunduk pada ketentuan PP Nomor 20 Tahun 1994 ini adalah PT Freeport Indonesia, tercatat hingga tahun 2001 PT Freeport Indonesia tidak juga melaksanakan divestasi saham yang termuat dalam ketentuan Pasal 24 ayat (2) Kontrak Karya yang menyatakan bahwa pada tahun ke-dua puluh pasca ditandatanganinya Kontrak Karya PT Freeport Indonesia harus melepaskan sahamnya kepada peserta nasional setidak-tidaknya 45\% apabila 20\% dari modal saham PT Freeport Indonesia dijual melalui Bursa Efek Jakarta atau 51\% apabila saham dilepaskan melalui penawaran langsung kepada peserta nasional. Hal ini terjadi karena dalam ketentuan PP Nomor 20 Tahun 1994 hanya mewajibkan saham yang dialihkan pada modal nasional hanya sebesar 5\%, sedangkan PT Freeport Indonesia pada 1991 telah melepaskan sahamnya pada PT Indocopper Investama yang saat itu dimiliki oleh PT Bakrie Investama

22 Asas lex posterior derogate legi priori, dimana aturan hukum yang lebih baru mengesampingkan atau meniadakan aturan hukum yang lama, asas lex posterior deregat legi priori mewajibkan menggunakan hukum yang baru.

${ }^{23}$ Undang-Undang Nomor 4 Tahun 2009 tentang Pertambangan Mineral dan Batubara, Pasal 112 ayat (1).

${ }^{24}$ Undang-Undang Nomor 4 Tahun 2009 tentang Pertambangan Mineral dan Batubara, Pasal 112 ayat (2), mengamanatkan bahwa ketentuan lebihlanjut mengenai divestasi akan diatur dalam Peraturan Pemerintah.
} 
IUPK setelah 5 tahun sejak berproduksi dengan presentase saham yang harus dilepaskan pada peserta Indonesia paling sedikit 20\%. ${ }^{25}$

Modal asing dalam ketentuan ini ialah modal yang dimiliki oleh negara asing, perseorangan warga negara, badan usaha asing, badan hukum asing, dan/atau badan hukum Indonesia yang seluruh modalnya dimiliki oleh pihak asing. ${ }^{26}$ Selain itu perusahaan juga diwajibkan untuk mempertahankan presentase kepemilikan peserta nasional tidak boleh terdelusi ${ }^{27}$ lebih kecil dari $20 \%$ apabila terjadi peningkatan jumlah modal di waktu yang akan datang.

Dua tahun berselang pemerintah mengeluarkan PP Nomor 24 Tahun 2012 tentang Perubahan atas PP Nomor 23 Tahun 2010. Ketentuan divestasi saham dalam PP Nomor 24 Tahun 2012 dirubah menjadi; Pemegang IUP dan IUPK dalam rangka penanaman modal asing (PMA), setelah 5 tahun sejak berproduksi wajib melakukan divestasi sahamnya secara bertahap, sehingga pada tahun kesepuluh sahamnya paling sedikit 51\% dimiliki peserta Indonesia. ${ }^{28}$ Dimana kepemiikan peserta Indonesia tersebut dalam setiap tahun setelah akhir tahun kelima sejak produksi tidak boleh kurang dari presentase berikut; a. tahun keenam $20 \%$; b. tahun ketujuh 30\%; c. tahun kedelapan 37\%; d. tahun kesembilan $44 \%$; e. tahun kesepuluh 51\%, dari jumlah seluruh saham.

PP Nomor 24 Tahun 2012 kemudian kembali dirubah melalui PP Nomor 77 Tahun 2014 sebagai perubahan ketiga dari PP Nomor 23 Tahun 2010. Kewajiban divestasi saham sebesar 51\% yang sebelumnya merupakan kewajiban mutlak bagi PMA pemegang IUP dan IUPK dan diatur secara umum bahwa divestasi saham merupakan kewajiban yang melekat pada pemegang IUP dan IUPK dengan ketentuan sudah berproduksi minimal 5 tahun. Ketentuan ini kemudian dirubah dalam PP Nomor 77 Tahun 2017 diman pemerintah membedakan kewajiban divestasi berdasarkan kriteria-kriteria tertentu. Kriteria-kriteria tersebut antara

25 Peraturan Pemerintah Nomor 23 Tahun 2010 tentang Pelaksanaan Kegiatan Usaha Pertambangan Mineral dab Batubara, Pasal 97 ayat (1).

26 Lihat Peraturan Pemerintah Nomor 23 Tahun 2010 tentang Pelaksanaan Kegiatan Usaha Pertambangan Mineral dab Batubara, Penjelasan Pasal 97 ayat (1).

${ }^{27}$ Dilusi adalah penurunan presentase kepemilikan atas saham pemegang saham yang sudah ada sebagai hasil dari penerbitan baru, Letezia Tobing, “Tentang Delusi Saham”, lihat https://www.hukumonline.com/ klinik/detail/ulasan/lt55499485f2890/tentang-dilusi-saham/, diakses pada 25 Oktober 2019.

28 Peraturan Pemerintah Nomor 24 Tahun 2012 tentang Perubahan Atas Peraturan Pemerintah Nomor 23 Tahun 2010 tentang Pelaksanaan Kegiatan Usaha Pertambangan Mineral dan Batubara, Pasal 97 ayat (1). 
lain. ${ }^{29}$ 1. Bagi PMA pemegang IUP Operasi Produksi dan IUPK Operasi Produksi yang tidak melakukan sendiri kegiatan pengolahan dan/atau pemurnian, setelah akhir tahun kelima sejak berproduksi paling sedikit sebagai berikut: tahun keenam $20 \%$; tahun ketujuh $30 \%$; tahun kedelapan 37\%; tahun kesembilan $44 \%$; dan tahun kesepuluh 51\%, dari jumlah seluruh saham. 2. Bagi PMA pemegang IUP Operasi Produksi dan IUPK Operasi Produksi yang melakukan sendiri kegiatan pengolahan dan/atau pemurnian, setelah akhir tahun kelima sejak berproduksi paling sedikit sebagai berikut: tahun keenam $20 \%$; tahun kesepuluh 30\%; dan tahun kelimabelas $40 \%$, dari jumlah seluruh saham. 3. Bagi PMA pemegang IUP Operasi Produksi dan IUPK Operasi Produksi yang melakukan kegiatan penambangan dengan menggunakan metode penambangan bawah tanah, setelah akhir tahun kelima sejak berproduksi paling sedikit sebagai berikut: tahun keenam 20\%; tahun kesepuluh $25 \%$; dan tahun kelimabelas $30 \%$; dari jumlah seluruh saham. 4. Bagi PMA pemegang IUP Operasi Produksi dan IUPK Operasi Produksi yang melakukan kegiatan penambangan dengan menggunakan metode penambangan bawah tanah dan penambangan terbuka, setelah akhir tahun kelima sejak berproduksi paling sedikit sebagai berikut: tahun keenam 20\%; tahun kedelapan 25\%; dan tahun kesepuluh 30\%; dari jumlah seluruh saham. 5. Bagi PMA Pemegang IUP Operasi Produksi khusus untuk pengolahan dan/atau pemurnian dalam rangka penanaman modal asing tidak wajib melaksanakan divestasi saham. 6. Bagi PMA Pemegang IUP Operasi Produksi dan IUPK Operasi Produksi yang sahamnya telah terdaftar di bursa efek di Indonesia diakui sebagai peserta Indonesia paling banyak 20\% dari jumlah seluruh saham.

Tiga tahun berselang PP Nomor 23 Tahun 2010 kembali dirubah melalui Perubahan Keempat yakni PP Nomor 1 Tahun 2017, dalam Peraturan Pemerintah ini ketentuan mengenai divestasi saham diatur kembali menjadi; Pemegang IUP

\footnotetext{
${ }^{29}$ Peraturan Pemerintah Nomor 77 Tahun 2014 tentang Perubahan Ketiga Peraturan Pemerintah Nomor 23 Tahun 2010 tentang Pelaksanaan Kegiatan Usaha Pertambangan Mineral dan Batubara, Pasal 97, dalam Politik Hukumnya PP Nomor 77 Tahun 2014, dibuat 2 bulan pasca penandatanganan MoU antara Pemerintah Indonesia dengan PT Freeport Indonesia pada 25 Juli 2014, dimana dalam MoU tersebut PT Freeport Indonesia menyatakan kesediaan melepas saham ke peserta Indonesia sebesar $30 \%$.
} 
dan IUPK dalam rangka penanaman modal asing, setelah 5 tahun sejak berproduksi wajib melakukan divestasi sahamnya secara bertahap, sehingga pada tahun kesepuluh sahamnya paling sedikit 51\% dimiliki peserta Indonesia. ${ }^{30}$ Dengan skema pelepasan saham sebagai berikut; a. tahun keenam $20 \%$; b. tahun ketujuh $30 \%$; c. tahun kedelapan $37 \%$; d. tahun kesembilan $44 \%$; e. tahun kesepuluhs 51\%, dari jumlah seluruh saham.

Dengan demikian, saat ini yang menjadi dasar pelaksanaan divestasi saham tunduk pada Pasal 97 Peraturan Pemerintah Nomor 1 Tahun 2017 tentang Perubahan Keempat atas Peraturan Pemerintah Nomor 23 Tahun 2010 tentang Pelaksanaan Kegiatan Usaha Pertambangan Mineral dan Batubara dimana ketentuan divestasi saham yang wajib laksanakan oleh PMA pemegang IUP dan IUPK Operasi Produksi sebesar 51\%.

Inkonsistensi pengaturan dalam pelaksanaan divestasi jelas menimbulkan ketidakpastian hukum baik bagi negara, penanam modal asing maupun calon penanam modal asing. Bahkan jika di telisik dari sejarahnya, Indonesia telah kehilangan banyak moment dan peluang penerimaan negara seharusnya diterima dari pelaksanaan divestasi.

Selain itu berubah-ubahnya regulasi divestasi saham dan ketidaktegasan Pemerintah juga mengakibatkan PMA di Indonesia menafsirkan hukum sesuai dengan kepentingannya masing-masing. Hal ini terjadi karena tidak ada kejelasan hukum mana yang sebenarnya berlaku. Ketidakpastian hukum dalam bidang pertambangan di Indonesia juga berdampak pada calon penanam modal yang pada akhirnya ragu-ragu untuk menanamkan modalnya di Indonesia.

\section{Divestasi Saham Sebagai Refleksi "Dikuasai Oleh Negara"}

Pasal 33 ayat (3) Undang-Undang Dasar 1945 yang menyatakan bahwa; 31 "Bumi, air, dan kekayaan alam yang terkandung di dalamnya dikuasai oleh negara dan dipergunakan sebesar-besar untuk kemakmuran rakyat". Makna dikuasai negara dalam Pasal 33 menurut Muhammad Hatta, ${ }^{32}$ ialah "dikuasai" bukan secara

\footnotetext{
30 Peraturan Pemerintah Nomor 1 Tahun 2017 tentang Perubahan Keempat Peraturan Pemerintah Nomor 23 Tahun 2010 tentang Pelaksanaan Kegiatan Pertambangan Mineral dan Batubara, Pasal 97 ayat (1).

${ }^{31}$ Lihat Undang-Undang Dasar Negara Republik Indonesia Tahun 1945, Pasal 33 ayat (3).

32 Mohammad Hatta sebagai salah satu the founding fathers bagi bangsa Indonesia merupakan perumus dan perancang dari Pasal 33, dimana pada hakikatnya Pasal 33 di latarbelakangi oleh semangat kolektifitas yang
} 
otomatis dikelola langsung oleh negara atau pemerintah, tetapi dapat menyerahkan pada pihak ketiga swasta yang disertai dengan pengawasan Pemerintah. ${ }^{33}$

Muhammad Hatta berpendapat bahwa negara tidak perlu menjadi pengusaha atau ondernemer. Negara lebih tepat dikatakan bahwa kekuasaan negara terdapat pada pembuat peraturan guna kelancaran jalan ekonomi. ${ }^{34}$ Akan tetapi, negara sebagai pembuat peraturan juga tidak dapat diartikan sebagai hak untuk mengatur, karena hal demikian sudah dengan sendirinya melekat fungsifungsi negara tanpa harus disebut secara khusus dalam Undang-Undang Dasar. ${ }^{35}$

Pemaknaan frasa "dikuasai oleh negara" dalam Pasal 33 ayat (3) UUD 1945 adalah negara tidak harus secara langsung ikut mengelola atau menyelenggarakan cabang produksi, akan tetapi dapat diserahkan kepada koperasi dan swasta. Sehubungan dengan itu, maka penguasaan negara dalam cabang-cabang produksi tersebut yang terpenting adalah bagaimana bentuk penguasaan negara itu dapat menjamin terselenggaranya kesejahteraan rakyat. ${ }^{36}$

Pemaknaan "dikuasai oleh negara" hingga saat ini masih menjadi perdebatan, hal ini terjadi dikarenakan pemaknaan dari setiap Undang-Undang berbeda. Selain itu belum ada "pakem" yang kuat terkait batas-batas maupun pemaknaan spesifik mengenai frasa "dikuasai oleh negara", untuk itu penulis akan mengkaji pemaknaan "dikuasai oleh negara" melalui Putusan Mahkamah Konstitusi Perkara Nomor 001-021-022/PUU-I/2003.

Pemaknaan "dikuasai oleh negara" dalam Perkara Nomor 001-021022/PUU-I/2003 tentang Permohonan Pengujian Undang-Undang Nomor 20

didasarkan pada semangat tolong-menolong (dikutip dari Moh. Hatta, Beberapa Pasal Ekonomi: Djalan Keekonomian dan Komerasi, Cetakan Ke-5, Perpustakaan Perguruan Kementerian P.P \&K, Jakarta, 1954, hlm. 265 dikutip oleh Suyanto Edi Wibowo, "Memahami Makna Pasal 33 Undang-Undang Dasar Negara Republik Indonesia Tahun 1945 Perihal Penguasaan Oleh Negara Terhadap Sumber Daya Alam, Jurnal Legislasi Indonesia”, 2018 http://ejurnal.peraturan.go.id/index.php/jli/article/download/424/304, hlm 2 diakses pada 30 Januari 2020).

33 Yusril Ihza Mahendra, Dinamika Tata Negara Indonesia Kompilasi Aktual Masalab Konstitusi Dewan Perwakilan san Sistem Kepartaian, Gema Insani Press, Jakarta, 1996, hlm. 55 dikutip oleh Tri Hayati, Hukum Pertambangan di Bawah Rezim UU No, 4 Tahun 2009, Yayasan Pustaka Obor Indonesia, Jakarta, 2015, hlm, 61

${ }^{34}$ Miriam Budiarjo, Dasar-Dasar Ilmu Politik, Cetakan Ke-17, Gramedia Pustaka Utama, Jakarta 1996, hlm. 45 dikutip oleh Tri Hayati, Era Baru Hukum Tambang.., Ibid.

35 Suyanto Edi Wibowo, Memahami Makna Pasal 33.., Op.Cit, hlm. 32

36 Tri Hayati, Era Baru Hukum Tambang..., Ibid, hlm. 62. 
Tahun 2002 tentang Ketenagalistrikan terhadap Undang-Undang Dasar, daiartikan sebagai;

"dikuasai oleh negara" haruslah diartikan mencakup makna penguasaan oleh negara dalam arti luas yang bersumber dan berasal dari konsepsi kedaulatan rakyat Indonesia atas segala sumber kekayaan "bumi dan air dan kekayaan alam yang terkandung di dalamnya", termasuk pula di dalamnya pengertian kepemilikan publik oleh kolektivitas rakyat atas sumber-sumber kekayaan dimaksud. Rakyat secara kolektif itu dikonstruksikan oleh UUD 1945 memberikan mandat kepada negara untuk mengadakan kebijakan (beleid) dan tindakan pengurusan (bestuursdaad), pengaturan (regelendaad), pengelolaan (beheersdaad) dan pengawasan (toezichthoudensdaad) untuk tujuan sebesar-besarnya kemakmuran rakyat. Fungsi pengurusan (bestuursdaad) oleh negara dilakukan oleh pemerintah dengan kewenangannya untuk mengeluarkan dan mencabut fasilitas perizinan (vergunning), lisensi (licentie), dan konsesi (concessie). Fungsi pengaturan oleh negara (regelendaad) dilakukan melalui kewenangan legislasi oleh DPR bersama dengan Pemerintah, dan regulasi oleh Pemerintah (eksekutif). Fungsi pengelolaan (beheersdaad) dilakukan melalui mekanisme pemilikan saham (share-holding) dan/atau melalui keterlibatan langsung dalam manajemen Badan Usaha Milik Negara atau Badan Hukum Milik Negara sebagai instrumen kelembagaan melalui mana negara c.q. Pemerintah mendayagunakan penguasaannya atas sumber-sumber kekayaan itu untuk digunakan bagi sebesar-besarnya kemakmuran rakyat. Demikian pula fungsi pengawasan oleh negara (toezichthoudensdaad) dilakukan oleh negara c.q. Pemerintah dalam rangka mengawasi dan mengendalikan agar pelaksanaan penguasaan oleh negara atas cabang produksi yang penting dan/atau yang menguasai hajat hidup orang banyak dimaksud benar-benar dilakukan untuk sebesar-besarnya kemakmuran seluruh rakyat;-------------------."

Dilihat dari pertimbangan putusan tersebut, Mahkamah memaknai dikuasai oleh negara sebagai rakyat memberikan mandat kepada negara secara kolektif dengan konstruksi UUD 1945, dimana rakyat memberikan mandat kepada negara untuk; Mengadakan kebijakan (beleid), melalui fungsi pengurusan (bestuursdaad), pengaturan (regelendaad), fungsi pengelolaan (beheersdaad), dan fungsi pengawasan (toezichthoudensdaad) untuk tujuan sebesarbesarnya kemakmuran rakyat.

Divestasi saham sebagai refleksi "dikuasai oleh Negara" dapat dikaji dan diuraikan sebagai berikut; 
1. Fungsi Pengurusan (bestuursdaad) oleh negara dilakukan oleh pemerintah dengan kewenangannya untuk mengeluarkan dan mencabut fasilitas perizinan (vergunning), lisensi (licentie), dan konsesi (concessie);

Fungsi pengurusan dalam divestasi saham dapat dilihat dari frasa "Modal asing Pemegang IUP dan IUPK". ${ }^{37}$ Dalam Undang-Undang Nomor 4 Tahun 2009. Kewenangan pemberian IUP dalam diatur dalam Pasal 37, dimana wewenang pemberian IUP diberikan oleh Menteri, Gubernur dan Bupati/Walikota sesuai dengan ketentuan perundang-undangan. Sedangkan pemberian IUPK merupakan wewenang mutlak menteri dengan memperhatikan kepentingan daerah diatur dalam Pasal 74 .

Sedangkan kewenangan untuk mencabut izin merupakan bagian sanksi administratif yang dimiliki oleh Menteri, Gubernur atau Bupati/walikota sesuai dengan kewenangan masing masing sebagaimana yang diatur dalam Pasal 151 sampai Pasal 157.

2. Fungsi Pengaturan oleh negara (regelendaad) dilakukan melalui kewenangan legislasi oleh DPR bersama dengan Pemerintah, dan regulasi oleh Pemerintah (eksekutif);

Fungsi pengaturan dalam divestasi saham dapat dilihat dari Pasal 112 ayat (2), dimana dalam rangka pelaksanaan pelaksanaan divestasi diatur lebih lanjut dalam Peraturan Pemerintah, yakni Peraturan Pemerintah Nomor 23 Tahun 2010 tentang Pelaksanaan Kegiatan Usaha Pertambangan Mineral dan Batubara sedangkan secara teknis tata cara divestasi dan mekanisme penetapan harga saham diatur dalam Peraturan Menteri.

3. Fungsi Pengelolaan (beheersdaad) dilakukan melalui mekanisme pemilikan saham (share-holding) dan/atau melalui keterlibatan langsung.

Fungsi pengelolaan dalam divestasi saham dapat dilihat dari Pasal 112 ayat Undang-Undang Nomr 4 Tahun 2009 jo Pasal 97 PP Nomor 1 Tahun 2017, yang didalamnya mengatur mengenai kewajiban divestasi saham sebesar $51 \%$ bagi penanam modal asing pemegang IUP dan IUPK Operasi Produksi.

37 IUP adalah Izin untuk melaksanakan usaha pertambangan sedangkan IUPK adalah izin untuk melaksanakan usaha pertambangan khusus. 
Majelis Konstitusi dalam Putusan Mahkamah Konstitusi Perkara Nomor 001021-022/PUU-I/2003 menyatakan bahwa;

“...penguasaan negara sebagai mana telah diuraikan di atas hal dimaksud harus dinilai berdasarkan Pasal 33 UUD 1945 secara keseluruhan, termasuk penyelenggaraan perekonomian nasional berdasar atas demokrasi ekonomi, prinsip kebersamaan, efisiensi berkeadilan, dan berwawasan lingkungan dengan mana ditafsirkan bahwa penguasaan negara juga termasuk dalam arti pemilikan privat yang tidak harus selalu 100\%. Artinya, pemilikan saham Pemerintah dalam badan usaha yang menyangkut cabang produksi yang penting bagi negara dan/atau yang menguasai hajat hidup orang banyak dimaksud, dapat bersifat mayoritas mutlak (di atas 50\%) atau bersifat mayoritas relatif (di bawah 50\%) sepanjang Pemerintah sebagai pemegang saham mayoritas relatif tersebut secara hukum tetap memegang kedudukan menentukan dalam pengambilan keputusan di badan usaha dimaksud;"

"Hal tersebut harus dipahami bahwa meskipun Pemerintah hanya memiliki saham mayoritas relatif dalam BUMN akan tetapi harus dipertahankan posisi negara untuk tetap sebagai pihak yang menentukan dalam proses pengambilan keputusan atas penentuan kebijakan dalam badan usaha yang bersangkutan yang menggambarkan penguasaan negara yang mencakup pengaturan, pengurusan, pengelolaan, dan pengawasan."

Dengan demikian secara yuridis normatif, jika dilihat pengaturan divestasi saham saat ini yang mewajibkan pelepasan saham sebesar 51\% merupakan angka yang cukup untuk dapat dikatakan sebagai saham mayoritas mutlak dalam suatu perusahaan sehingga secara umum telah mengandung nilai-nilai penguasaan negara.

4. Fungsi Pengawas (toezichthoudensdaad) dilakukan oleh negara melalui pemerintah dalam rangka mengawasi dan mengendalikan agar pelaksanaan penguasaan oleh negara atas sumber-sumber kekayaan dimaksud benar-benar dilakukan untuk sebesar-besarnya kemakmuran rakyat.

Fungsi pengawasan dalam divestasi saham dapat dilihat dari masuknya pemerintah atau keterlibatan pemerintah dalam pelaksanaan divestasi, baik secara langsung maupun melalui BUMN. Dalam Divestasi saham PT Freeport Indonesia, Pemerintah menjalankan fungsi pengawasan setelah dilaksanakannya penyertaan modal melalui PP Nomor 47 Tahun 2017 tentang 
Penambahan Penyertaan Modal Negara Republik Indonesia Ke Dalam Modal

Saham Perusahaan Perseroan (Persero) PT Indonesia Asahan Aluminium. ${ }^{38}$

Melalui penambahan penyertaan modal tersebut pemerintah turut mengalihkan saham PT Freeport Indonesia ke pada PT Inalum yang kemudian akan di kelola oleh PT Inalum dan kontrol atas perusahaan (PT Inalum, PT Bukit Asam, PT Antam, PT Timah dan PT Freeport) akan dilaksanakan melalui saham seri A Dwi Warna. ${ }^{39}$

Dengan demikian, pengaturan divestasi saham dalam Pasal 112 UndangUndang Nomor 4 Tahun 2009 jo PP Nomor 1 Tahun 2017 telah merefleksikan “Dikuasai Oleh Negara” sebagaimana yang telah diamanatkan dalam Pasal 33 ayat (3) Undang-Undang Dasar 1945.

\section{Penutup}

Berdasarkan analisis di atas dapat disimpulkan; Pertama, peraturan divestasi saham yang terus berubah-ubah mengakibatkan ketidakpastian hukum baik bagi negara, penanam modal asing maupun calon penanam modal asing. Bahkan jika di telisik dari sejarahnya, Indonesia telah kehilangan banyak peluang penerimaan negara yang akan diterima dari pelaksanaan divestasi saham. Selain itu, berubahubahnya regulasi divestasi saham dan ketidaktegasan Pemerintah juga mengakibatkan penanam modal asing di Indonesia menafsirkan hukum sesuai dengan kepentingannya masing-masing. Hal ini terjadi karena tidak ada kejelasan hukum mana yang sebenarnya berlaku. Ketidakpastian hukum dalam bidang pertambangan di Indonesia juga berdampak pada calon penanam modal yang pada akhirnya ragu-ragu untuk menanamkan modalnya di Indonesia.

Kedua, divestasi saham telah memenuhi fungsi pengurusan (bestuursdaad), fungsi pengaturan oleh negara (regelendaad), fungsi Pengelolaan (beheersdaad) dan fungsi Pengawas (toezichthoudensdaad), sebagimana penafsiran "dikuasai oleh

\footnotetext{
38 Peraturan Pemerintah 47 Nomor Tahun 2017 tentang Penambahan Penyertaan Modal Saham Perusahaan Perseroan (Persero) PPT Indonesia Asahan Alumunium.

39 M. Agus Yozami, PP Holding BUMN Tambang Terbit, Pemerintah Kendalikan 4 Hal, Lihat https://www.hukumonline.com/berita/baca/lt5a17ed280f936/pp-holding-bumn-tambang-terbit--pemerintahkendalikan-4-hal/, diakses pada 10 Maret 2020.
} 
negara" Mahkamah Konstitusi dalam Perkara Nomor 001-021-022/PUU-I/2003.

Dengan demikian, pengaturan divestasi saham dalam Pasal 112 Undang-Undang Nomor 4 Tahun 2009 jo PP Nomor 1 Tahun 2017 telah merefleksikan “Dikuasai Oleh Negara" sebagaimana yang telah diamanatkan dalam Pasal 33 ayat (3) Undang-Undang Dasar 1945.

\section{Daftar Pustaka}

\section{Buku}

Bendar, Amin, Hukum Penanaman Modal Asing Implementasi Pertambangan di Indonesia, FH UII Press, Yogyakarta, 2018.

Hayati, Tri, Hukum Pertambangan di Bawah Rezim UU No. 4 Tahun 2009, Yayasan Pustaka Obor Indonesia, Jakarta, 2015.

HS Salim dan Erlies Septiana Nurbani, Hukum Divestasi di Indonesia (Pascan Putusan Mahkamah Konstitusi RI Nomor 2/SKLN-X/2010), RajaGrafindo Persada, Jakarta, 2013.

Ilma, Aminuddin, Hukum Penanaman modal Indonesia, Kencana, Jakarta, 2004.

Pria, Lalu Wira, Prinsip Hukum Investasi Pertambangan Umum, Genta Publishing, Surakarta, 2014.

Rajaguguk, Erman, Indonesianisasi Saham, Bina Aksara, Jakarta 1986.

Siti Anisah dan Lucky Suryo wicaksono, Hukum Investasi, FH UII Press, Yogyakarta, 2014.

Soekanto, Soerjono, Pengantar Penelitian Hukum, cet. ketiga, Universitas Indonesia, Jakarta, 1986.

\section{Hasil Penelitian}

Hasanudin, Maulana, Perusahaan Joint Venture, Tesis, Pascsarjana FH UI, Jakarta, 2010.

\section{Jurnal}

Wibowo, Suyanto Edi, "Memahami Makna Pasal 33 Undang-Undang Dasar Negara Republik Indonesia Tahun 1945 Perihal Penguasaan Oleh Negara Terhadap Sumber Daya Alam", Jurnal Legislasi Indonesia, 2018.

\section{Internet}

Cahyono, Eddy Investasi dan Pembangunan Ekonomi, lihat https://setkab.go.id/ investasi-dan-pembangunan-ekonomi/ diakses pada 7 April 2019.

Tobing, Letezia, Tentang Delusi Saham, lihat https://www.hukumonline. com/klinik/detail/ulasan/lt55499485f2890/tentang-dilusi-saham/ diakses pada 25 Oktober 2019 
Yozami, M. Agus, PP Holding BUMN Tambang Terbit, Pemerintah Kendalikan 4 Hal, Lihat https://www.hukumonline.com/berita/baca/lt5a17ed280f936/ pp-holding-bumn-tambang-terbit--pemerintah-kendalikan-4-hal/, diakses pada 10 Maret 2020

\section{Peraturan-Perundang Undangan}

Undang-Undang Dasar Negara Republik Indonesia Tahun 1945

Undang-Undang Nomor 4 Tahun 2009 tentang Pertambangan Mineral dan Batubara

Peraturan Pemerintah Nomor 1 Tahun 2017 tentang Perubahan Keempat Peraturan Pemerintah Nomor 23 Tahun 2010 tentang Pelaksanaan Kegiatan Pertambangan Mineral dan Batubara

Peraturan Pemerintah Nomor 17 Tahun 1992 tentang Persyaratan Pemilikan Saham dalam Penanaman Modal Asing

Peraturan Pemerintah Nomor 20 Tahun 1994 tentang Persyaratan Pemilikan Saham dalam Perusahaan Penanaman Modal Asing,

Peraturan Pemerintah Nomor 24 Tahun 2012 tentang Perubahan Atas Peraturan Pemerintah Nomor 23 Tahun 2010 tentang Pelaksanaan Kegiatan Usaha Pertambangan Mineral dan Batubara

Peraturan Pemerintah Nomor 47 Tahun 2017 tentang Penambahan Penyertaan Modal Saham Perusahaan Perseroan (Persero) PPT Indonesia Asahan Alumunium

Peraturan Pemerintah Nomor 77 Tahun 2014 tentang Perubahan Ketiga Peraturan Pemerintah Nomor 23 Tahun 2010 tentang Pelaksanaan Kegiatan Usaha Pertambangan Mineral dan Batubara

\section{Putusan Pengadilan}

Putusan Mahkamah Konstitusi Perkara Nomor 001-021-022/PUU-I/2003 